Cite this: Metallomics, 2013, 5, 1377

Received 22nd March 2013, Accepted 28th June 2013

DOI: $10.1039 / \mathrm{c} 3 \mathrm{mt} 00088 \mathrm{e}$

www.rsc.org/metallomics

\section{Different strategies of cadmium detoxification in the submerged macrophyte Ceratophyllum demersum $\mathrm{L}$.}

\author{
Elisa Andresen, ${ }^{a}$ Jürgen Mattusch, ${ }^{b}$ Gerd Wellenreuther, ${ }^{c}$ George Thomas, ${ }^{a}$ \\ Uriel Arroyo Abad ${ }^{\mathrm{b}}$ and Hendrik Küpper*ad
}

\begin{abstract}
The heavy metal cadmium (Cd) is highly toxic to plants. To understand the mechanisms of tolerance and resistance to $\mathrm{Cd}$, we treated the rootless, submerged macrophyte Ceratophyllum demersum $\mathrm{L}$. with sub-micromolar concentrations of $\mathrm{Cd}$ under environmentally relevant conditions. X-ray fluorescence measurements revealed changing distribution patterns of $\mathrm{Cd}$ and $\mathrm{Zn}$ at non-toxic $(0.2 \mathrm{nM}, 2 \mathrm{nM})$, moderately toxic $(20 \mathrm{nM})$ and highly toxic $(200 \mathrm{nM})$ levels of $\mathrm{Cd}$. Increasing $\mathrm{Cd}$ concentrations led to enhanced sequestration of $\mathrm{Cd}$ into non-photosynthetic tissues like epidermis and vein. At toxic $\mathrm{Cd}$ concentrations, $\mathrm{Zn}$ was redistributed and mainly found in the vein. $\mathrm{Cd}$ treatment induced the synthesis of phytochelatins (PCS) in the plants, with a threshold of induction already at $20 \mathrm{nM} C d$ for $P C_{3}$. In comparison, in plants treated with $\mathrm{Cu}$, elevated PC levels were detected only at the highest concentrations (100-200 nM Cu). Our results show that also non-accumulators like $C$. demersum store toxic metals in tissues where the heavy metal interferes least with metabolic pathways, but remaining toxicity interferes with micronutrient distribution. Furthermore, we found that the induction of phytochelatins is not proportional to metal concentration, but has a distinct threshold, specific for each PC species. Finally we could show that $20 \mathrm{nM} \mathrm{Cd}$, which was previously regarded as non-toxic to most plants, already induces detoxifying mechanisms.
\end{abstract}

\section{Introduction}

Cadmium is an important environmental pollutant and toxic to most organisms. It is highly water soluble, rather immobile in soils but nevertheless can easily accumulate in plants, thus entering the human food chain. ${ }^{1} \mathrm{Cd}$ concentrations in the environment range from 0.2 to $0.4 \mathrm{nM}$ in unpolluted areas (e.g. Lake Constance) $)^{2,3}$ to $5 \mathrm{nM}$ in different slightly contaminated rivers in Germany. ${ }^{4} \mathrm{Cd}$ release from car tires increased $\mathrm{Cd}$ concentration to $\sim 17 \mathrm{nM}$ in New Zealand. ${ }^{5}$ And in a heavily contaminated stream in North Central Nigeria, Cd concentrations of $17 \mathrm{nM}, 195 \mathrm{nM}$ and $1334 \mathrm{nM}$ were measured. ${ }^{6}$ Although there are some indications that $\mathrm{Cd}$ may have a positive effect at

\footnotetext{
${ }^{a}$ Department of Biology, University of Konstanz, 78457 Konstanz, Germany. E-mail: Elisa.Andresen@uni-konstanz.de, George.Thomas@uni-konstanz.de, Hendrik.Kuepper@uni-konstanz.de; Fax: +497531 884533; Tel: +497531884112

${ }^{b}$ Department of Analytical Chemistry, UFZ - Helmholtz Centre for Environmental Research, Permoserstr. 15, 04317 Leipzig, Germany. E-mail: Juergen.Mattusch@ufz.de, Uriel.Arroyo-Abad@ufz.de ${ }^{c}$ HASYLAB at DESY, Notkestr. 85, 22603 Hamburg, Germany. E-mail: Gerd.Wellenreuther@desy.de

${ }^{d}$ Faculty of Biological Sciences and Institute of Physical Biology, University of South Bohemia, Branišovská 31, 37005 České Budejovice, Czech Republic
}

very low concentrations (e.g. in Zn-limited diatoms), ${ }^{7}$ there is overwhelming evidence for Cd-induced toxicity in plants. ${ }^{8,9}$ Due to chemical similarity of $\mathrm{Cd}$ with $\mathrm{Zn}$, many toxic effects of $\mathrm{Cd}$ are correlated with $\mathrm{Zn}$ limitation or replacement, starting with uptake into the plants by transporters with similar affinities for $\mathrm{Cd}$ and $\mathrm{Zn}^{.}{ }^{10,11}$ However, both synergistic and antagonistic effects of $\mathrm{Cd}$ on $\mathrm{Zn}$ accumulation have been found in roots and shoots, depending on cultivar and the genotype of wheat ${ }^{12}$ and tomato seedlings. ${ }^{13}$

As plants cannot avoid unfavorable conditions like soils with high heavy metal concentrations, they developed several detoxification methods, including immobilization, exclusion, chelation and compartmentalization. ${ }^{8,14}$ One group of detoxifying substances are the enzymatically synthesized phytochelatins (PCs), which after their discovery ${ }^{15}$ have been found in higher plants, algae, yeast, some fungi (see review by Clemens, $2006^{11}$ and citations within) and also in the nematode C. elegans. ${ }^{16}$ Phytochelatins have the general structure ( $\gamma$ Glu-Cys) $n$-Gly (with $n=2$ to 11 ) and are generated by the constitutive enzyme phytochelatin synthase (PCS), which is post-translationally activated only after blockage of thiols by a broad range of heavy metal(loid)s, ${ }^{17}$ most efficiently by $\mathrm{Cd}$ and As, but also by $\mathrm{Ag}, \mathrm{Pb}$, $\mathrm{Cu}, \mathrm{Hg}, \mathrm{Zn}, \mathrm{Sn}$, and Au. ${ }^{11,18}$ Metal-PC-complexes are most likely 
transported into and stored in the vacuole where the heavy metal(loid)s cannot interfere with photosynthetic actions.

The storage of heavy metal(loid)s in compartments or tissues where they cannot damage metabolic pathways is a general tolerance mechanism for reducing the amount of heavy metal(loid)s in the cytosol. Furthermore, the few enzymes found in the vacuole ${ }^{19}$ have never been found to be sensitive to heavy metal stress. This protective mechanism is best studied in hyperaccumulator plants. These plants actively accumulate $>100 \mathrm{ppm} \mathrm{Cd},>1000 \mathrm{ppm} \mathrm{Cu}$ or $\mathrm{Ni}$, or >10 000 ppm Zn in their above ground tissues. ${ }^{20}$ It should be noted that it was suggested to change the definition of "hyperaccumulator" to $>500 \mathrm{ppm} \mathrm{Cd}$ in shoots under environmentally relevant conditions with less than $20 \%$ growth reduction until the stage of maturity and a bioaccumulation coefficient $>5$ at a Cd concentration leading to $>500$ ppm in shoots. ${ }^{21}$ By tolerating heavy metals, these plants gain advantage over related non-accumulator species as they can colonize soils with elevated heavy metal concentrations. Due to the specialization, many metallophytes become endemic to metalliferous soils. ${ }^{22}$ Compared to equally metal-tolerant nonaccumulators, hyperaccumulators have the additional benefit of being protected against herbivores. This was originally shown in 1994, ${ }^{23,24}$ and since then has been shown for many further metals and plant species including the $\mathrm{Cd} / \mathrm{Zn}$ hyperaccumulator (formally Thlaspi) Noccaea caerulescens: the Cd-accumulation deterred thrips (Frankliniella occidentalis) from feeding on $N$. caerulescens leaves. ${ }^{25}$ It was shown that especially the vacuole of large epidermal cells is used for the storage of the heavy metals. ${ }^{26-28}$ Küpper et al. found that in $N$. caerulescens the relative Zn concentration in epidermal cells was positively correlated with cell length in young as well as in mature leaves. ${ }^{26}$ In the related species $N$. praecox collected from a heavy-metal polluted area in Slovenia, Cd was localized in the epidermis, the vascular bundle, but also the mesophyll while $\mathrm{Zn}$ was preferentially accumulated in the epidermis cells. ${ }^{29}$ Also in the non-accumulator Anthyllis vulneraria, cadmium depositions were found in the central vein, in epidermis cells and in the (epidermal) trichomes. ${ }^{30}$

There are different techniques to investigate metal accumulation in plants. If one is interested in the cellular or sub-cellular distribution, however, it is important to analyze intact tissues as fragmentation will disrupt the different organelles: metals that were bound to weak ligands in the vacuole may bind stronger ligands present in the cytosol. ${ }^{31}$ For the same reason any fixation techniques besides rapid freezing should be avoided. In this study, we used $\mu$-X-ray fluorescence to determine the localization of $\mathrm{Cd}$, $\mathrm{Zn}$ and $\mathrm{Cu}$ in frozen hydrated leaves of the rootless, submerged macrophyte Ceratophyllum demersum. It is sensitive to heavy metal stress and as it does not possess roots, no root-specific inhibition or detoxification mechanisms are possible.

\section{Results}

\section{Toxicity determination}

Cadmium treatment led to a reduction in the maximum quantum efficiency of PSII photochemistry, measured as $F_{\mathrm{v}} / F_{\mathrm{m}}=\left(F_{\mathrm{m}}-F_{0}\right) /$ $F_{\mathrm{m}}$ (Fig. 1). While the values were constant over the treatment

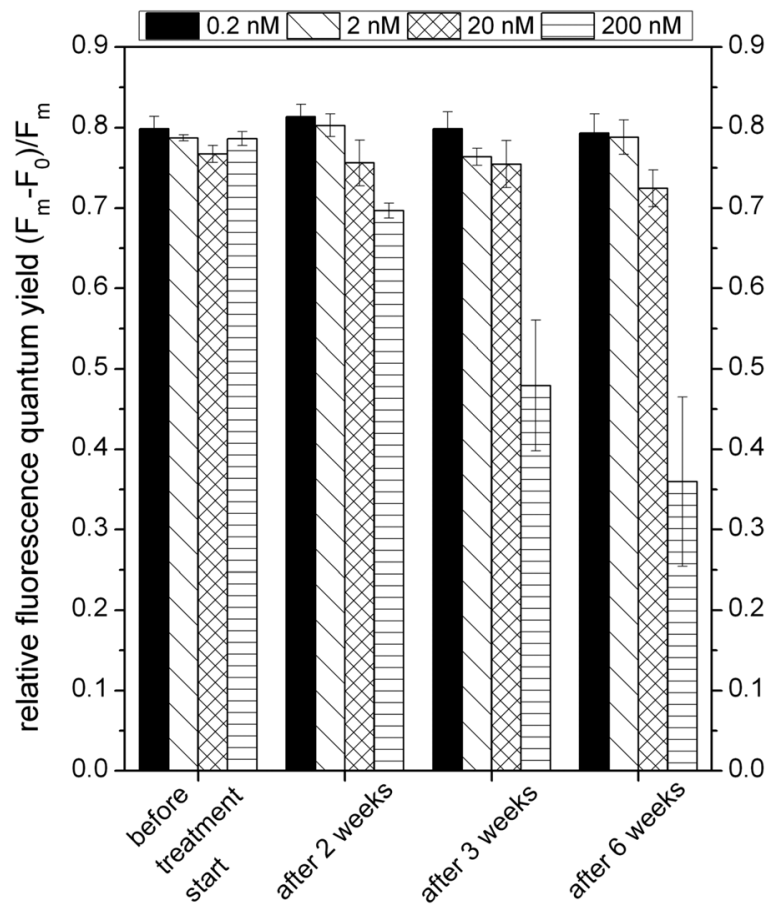

Fig. 1 Fluorescence quantum yield of PS II measured as $F_{\mathrm{v}} / F_{\mathrm{m}}=\left(F_{\mathrm{m}}-F_{0}\right) / F_{\mathrm{m}}$ before treatment start and at different times during the treatment duration for $0.2,2,20$ and $200 \mathrm{nM}$ of $C d . F_{0}=$ minimal fluorescence quantum yield in darkadapted tissue; all PSII reaction centers open, $F_{m}=$ maximal fluorescence quantum yield in dark adapted tissues; all PSII reaction centers closed. $F_{\mathrm{v}}=$ variable fluorescence. Values are from 2 experiments and 2 different leaves each. Error bars show error of the mean.

duration for the control $(0.2 \mathrm{nM})$ and the low Cd concentration ( $2 \mathrm{nM}$ ), a slight decrease occurred for the plants treated with $20 \mathrm{nM}$ Cd towards the end of the treatment $(P=0.051)$. The plants treated with the highest $\mathrm{Cd}$ concentration showed a clear reduction of $F_{\mathrm{v}} / F_{\mathrm{m}}$ from the 2 nd week onwards. The Cd-induced inhibition of the photosynthetic apparatus is a great threat to photosynthetic organisms as it was shown to be an important inhibition site. ${ }^{9}$ And although the decrease in $F_{\mathrm{v}} / F_{\mathrm{m}}$ is often part of a very complicated phenotype, it was established as a stress monitor. ${ }^{32}$

\section{Phytochelatin determination - method evaluation}

After extraction of phytochelatins with a cooled aqueous solution of $1 \%$ formic acid, their high-resolution separation by UHPLC and their detection using ICP-MS and ESI-Q-TOF-MS in parallel was successfully applied within $10 \mathrm{~min}$ for $\mathrm{PC}_{2}$ to $\mathrm{PC}_{6}$. The ESI-Q-TOF-MS allows the detection of accurate masses with an $\mathrm{m} / \mathrm{z}$ error less than $3 \mathrm{ppm}$. With these accurate masses, proposals for ion formulas were created and used for the identification of reduced and oxidized PCs in the plant extracts. In the present case the parallelly occurring ICP-MS detection was applied to quantify the uncomplexed $\mathrm{Cd}$ ions in the extracts because the acidic mode of extraction and separation does not allow the analysis of initial Cd-PC-complexes. Despite the dissociation of the Cd-PC-complexes, an excellent chromatographic separation of the free reduced and oxidized PCs can be performed using 


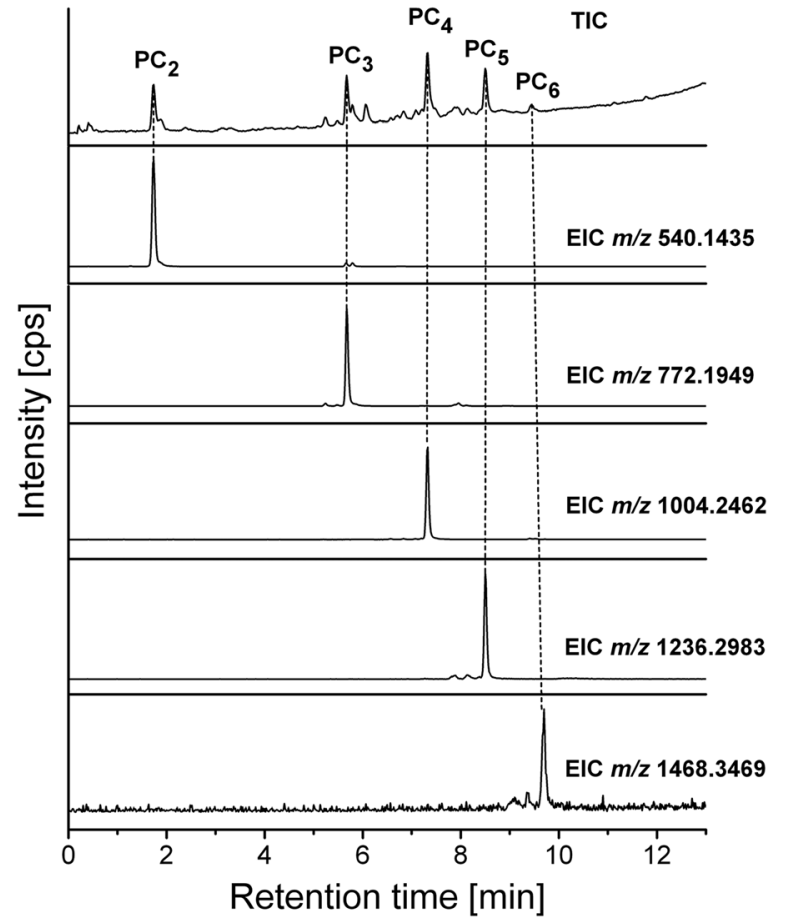

Fig. 2 UHPLC-ESI-Q-TOF-MS chromatograms (Total lon Counting (TIC); Extracted lon Counting (EIC)) of a $\mathrm{PC}$ standard solution containing $\mathrm{PC}_{2}, \mathrm{PC}_{3}, \mathrm{PC}_{4}, \mathrm{PC}_{5}$, and $\mathrm{PC}_{6}$ each with a concentration of $30 \mu \mathrm{M}$.

$0.1 \%$ formic acid combined with an acetonitrile gradient as an eluent. The dissociation of the complexes is not a drawback for the aim of our work, because grinding tissues anyhow leads to mixing of all soluble constituents of all cells and cellular compartments so that originally weakly bound metals from the vacuole would be mixed with strong ligands, e.g. PCs, in the cytoplasm. Thus immediate binding of previously weakly bound $\mathrm{Cd}$ to the PCs would occur once the ground plant material melts. Therefore, we concentrated on identifying and quantifying the different phytochelatin species. Fig. 2 and Table 1 present qualitative values for the identified reduced and oxidized PCs under investigation. In Fig. 2 the ESI-Q-TOF-MS signals (total ion current (TIC) and extracted ion current (EIC)) are presented and used for identification and quantification of PCs in the plant extracts. Additionally to the reduced PCs, also the oxidized PC isomers were considered for quantification. The $y$-axis scales for each EIC were adjusted for an optimal view of the peaks. In Fig. 2 the shoulder on the $\mathrm{PC}_{3}$ peak could be identified as $\left(\mathrm{PC}_{2}\right)_{2}$. In this case two $\mathrm{PC}_{2} \mathrm{~S}$ are linked together via an inter disulphide bridge. In Fig. 3 the peak at $3.08 \mathrm{~min}$ has an accurate mass of $\mathrm{m} / \mathrm{z}$ 595.1433 that did not correspond to known canonic and iso-PCs. The peak at 5.485 min could be identified as an isomer of oxPC$_{3}$.

\section{Phytochelatin induction}

Cadmium treatment induced phytochelatin synthesis in the plants (Fig. 4; $P<0.001,2$-way ANOVA). The induction of phytochelatins was not proportional to metal concentration, but had a distinct threshold, specific for each PC species: while $\mathrm{PC}_{2}$ was the only PC-species detected in both tissue ages of all
Table 1 Retention time, theoretical and experimental $\mathrm{m} / \mathrm{z}$ and mass error $\Delta$ of selected PCs

\begin{tabular}{|c|c|c|c|c|}
\hline PCs & $\begin{array}{l}\text { Retention } \\
\text { time (min) }\end{array}$ & $\mathrm{m} / \mathrm{z}$ theor. & $m / z$ exper. & $\Delta \mathrm{m} / \mathrm{z}(\mathrm{ppm})$ \\
\hline $\mathrm{PC}_{2}$ & 1.774 & 540.1429 & 540.1435 & 1.1 \\
\hline $\mathrm{OxPC}_{2}$ & 1.936 & 538.1272 & 538.1267 & 0.9 \\
\hline $\mathrm{PC}_{3}$ & 5.705 & 772.1946 & 772.1949 & 0.4 \\
\hline $\mathrm{oxPC}_{3}$ isomers & $\begin{array}{l}5.241 \\
5.485 \\
5.875\end{array}$ & 770.1790 & 770.1800 & 1.3 \\
\hline $\mathrm{PC}_{4}$ & 7.363 & 1004.2464 & 1004.2462 & 0.2 \\
\hline $\mathrm{oxPC}_{4}$ isomers & $\begin{array}{l}6.590 \\
6.850 \\
7.094 \\
7.207 \\
7.500\end{array}$ & 1002.2308 & 1002.2298 & 1 \\
\hline $\mathrm{PC}_{5}$ & 8.532 & 1236.2982 & 1236.2983 & 0.1 \\
\hline $\mathrm{oxPC}_{5}$ isomers & $\begin{array}{l}7.662 \\
7.906 \\
8.150 \\
8.393 \\
8.588\end{array}$ & 1234.2825 & 1234.2834 & 0.7 \\
\hline $\mathrm{PC}_{6}$ & 9.475 & 1468.3500 & 1468.3469 & 2.1 \\
\hline
\end{tabular}

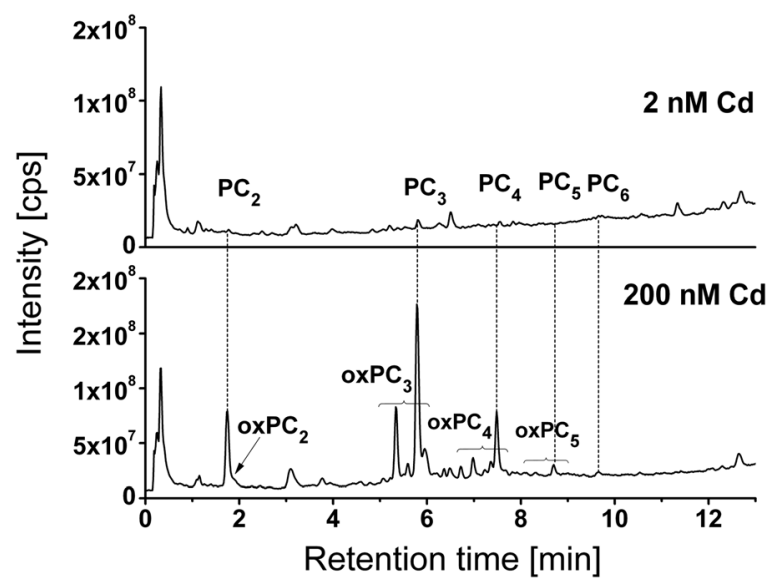

Fig. 3 UHPLC-ESI-Q-TOF-MS chromatograms of extracts originating from young plants under different $\mathrm{Cd}$ stress conditions.

extracts, $\mathrm{PC}_{6}$ was present mainly in extracts from the higher $\mathrm{Cd}$ treatments. In the control treatment (no Cd added; $0.2 \mathrm{nM}$, background concentration), only trace amounts of $\mathrm{PC}_{2}$ and $\mathrm{PC}_{3}$ were detected. $\mathrm{PC}_{2}$ levels in the young tissue significantly differed only between the lowest (control and $1 \mathrm{nM} \mathrm{Cd}$ ) and the highest $\mathrm{Cd}$ concentrations $(P=0.001)$. In the old tissue, $\mathrm{Cd}$ concentrations from $0.2 \mathrm{nM}$ up to $10 \mathrm{nM}$ led to different $\mathrm{PC}_{2}$ inductions from both $100 \mathrm{nM}$ and $200 \mathrm{nM} \mathrm{Cd}$. Altogether, this means that induction of $\mathrm{PC}_{2}$ by Cd stress was rather weak. $\mathrm{PC}_{3}$, in contrast, had the most prominent induction in response to the metal treatments and yielded the highest amounts. The $\mathrm{PC}_{3}$ content was not different within the group of low $\mathrm{Cd}$ $(0.2-10 \mathrm{nM})$ or the group of high $\mathrm{Cd}(20-200 \mathrm{nM})$ in young tissue, but between these two groups $(P \leq 0.002)$, emphasizing the switch-like response of $\mathrm{PC}_{3}$ synthesis. Regarding the old tissue, only the two highest Cd concentrations induced $\mathrm{PC}_{3}$ in amounts different from the other $\mathrm{Cd}$ concentrations. $\mathrm{PC}_{4}$ was 


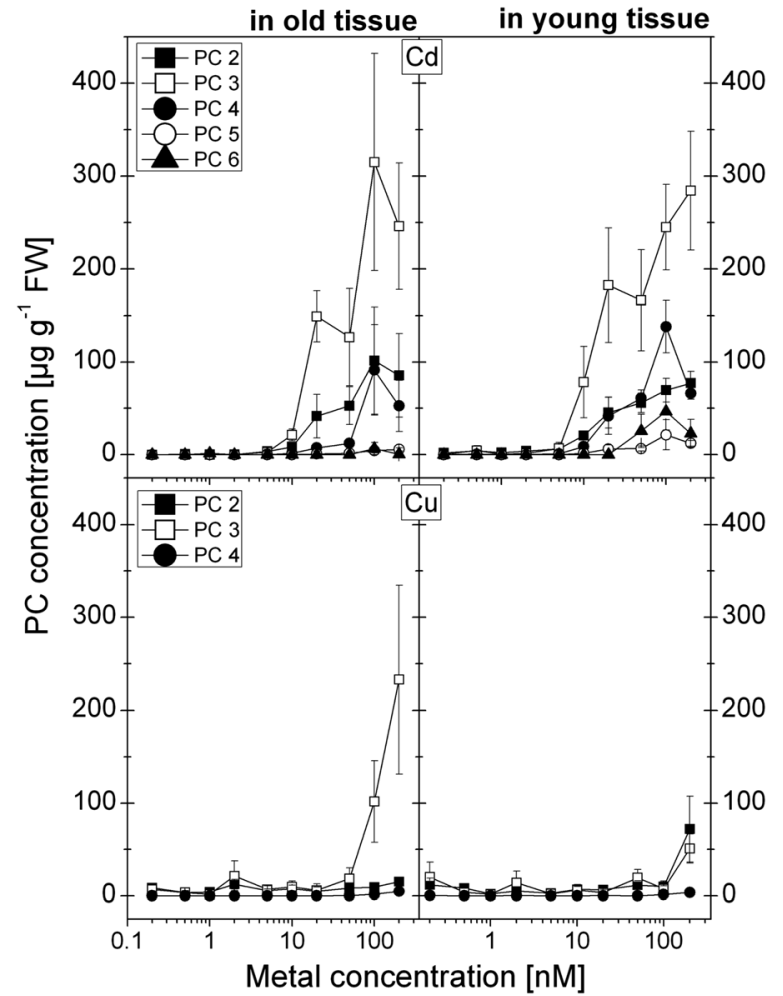

Fig. 4 Induction of different phytochelatin species after 2 (Cd) or 2 \& 4 (Cu) weeks of metal treatment in young and old tissues. Values are averages of 2 experiments and 2 technical replicates. Error bars show error of the mean.

present in most extracts, but not detected in the control plants, in young tissue of the plants treated with $1 \mathrm{nM}$ and $2 \mathrm{nM}$, and in old tissue of the plants at $0.5 \mathrm{nM} \mathrm{Cd}$. Up to $5 \mathrm{nM} \mathrm{Cd}$ for the young and $10 \mathrm{nM}$ for the old tissues, the amounts of $\mathrm{PC}_{4}$ were very low. Moderately elevated (maximum like $\mathrm{PC}_{2}$ ) levels of $\mathrm{PC}_{4}$ occurred for the young tissue in the three highest Cd treatments, for the old tissue only in the $100 \mathrm{nM}$ treatment. Compared to the shorter PCs, $\mathrm{PC}_{5}$ was detected only in trace amounts, mostly from $10 \mathrm{nM}$ (young tissue) or $20 \mathrm{nM} \mathrm{Cd}$ (old tissue) onwards. $\mathrm{PC}_{6}$ was detected only in the plants treated with the highest $\mathrm{Cd}$ concentrations $\left(50,100,200 \mathrm{nM} \mathrm{Cd}\right.$ for $\mathrm{PC}_{6^{-}}$ induction in young tissue; $100,200 \mathrm{nM} \mathrm{Cd}$ for $\mathrm{PC}_{6}$-induction in old tissue), with the exception of a trace amount being detected in the old tissue of the plant treated with $1 \mathrm{nM} \mathrm{Cd}$. Generally, the respective amounts of $\mathrm{PC}_{6}$ were much higher in the young than the old tissues $(P<0.008)$; in young tissues $\mathrm{PC}_{6}$ reached double the maximum concentration compared to $\mathrm{PC}_{5}$. Phytochelatins were also extracted from Cu-treated plants, in order to compare the induction threshold because $\mathrm{Cu}$ is an essential metal and not a main inducer of PCs (Fig. 4). Here, only $\mathrm{PC}_{2}$ and $\mathrm{PC}_{3}$ were detected in all samples. The respective contents were only significant in the old tissue of plants treated with $200 \mathrm{nM} \mathrm{Cu} . \mathrm{PC}_{4}$ was present, only in trace amounts, solely in the young tissue of some plants $(0.2,1,2,20,100,200 \mathrm{nM} \mathrm{Cu})$ and in the old tissue in plants treated with $50 \mathrm{nM}$ or more $\mathrm{Cu}$. In all copper-treated plants, the amounts of the respective PCs were much lower than in the plants treated with cadmium.

\section{Elemental accumulation and distribution}

The higher the applied Cd concentration, the higher was the $\mathrm{Cd}$ accumulation in the leaf as revealed by $\mu$-XRF (Fig. 5, left panel). Also when looking at the whole-plant level as analyzed by GF-AAS in acid-digests of tissues, the Cd accumulation within the young and old tissue after 6 weeks of treatment was found to increase with the applied concentration (Table 2).

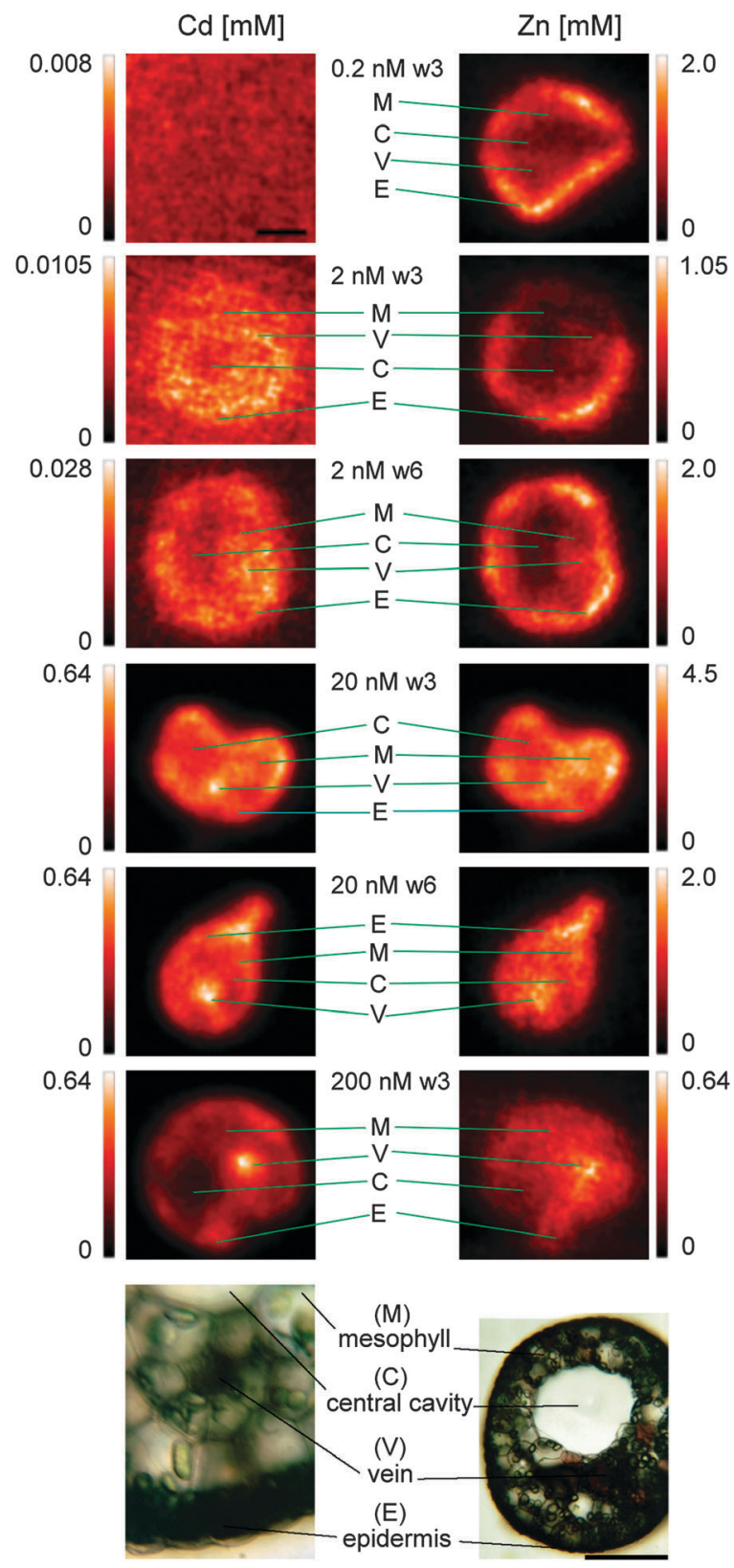

Fig. $5 \mu$-XRF imaging of C. demersum leaves treated for 3 or 6 weeks with different $\mathrm{Cd}$ concentrations shown for $\mathrm{Cd}$ and $\mathrm{Zn}$ of the same leaf containing the light microscope picture of a cross section through a C. demersum leaf with tissue identification. The position of the different structures was verified by comparing the shown $\mu$-XRF images with the ones for other elements (e.g. $\mathrm{Cu}$ ). For each concentration, $2(0.2 \mathrm{nM}, 2 \mathrm{nM} w 6,20 \mathrm{nM} w 6)$ or $3(2 \mathrm{nM} w 3,20 \mathrm{nM} w 3$, $200 \mathrm{nM}$ ) different leaves from different plants of the same experiment were measured. Scale bar $=100 \mu \mathrm{m}$. Note that individual scales were used. 
Table $2 \mathrm{Cd}, \mathrm{Zn}$ and $\mathrm{Cu}$ accumulation in young and old tissues after 6 weeks of treatment with 0.2, 2, 20 or $200 \mathrm{nM}$ Cd. Values are averages from 2 experiments and technical triplicates within AAS measurement. Error $=$ standard error of the mean. Different letters in the $\mathrm{Cd}$ column indicate significant differences $(P<0.05)$ according to the Holm-Sidak method (2-way-ANOVA with comparison of age and applied Cd concentration). Accumulation of Cu and Zn did not differ depending on the $\mathrm{Cd}$ treatment $(P>0.4)$

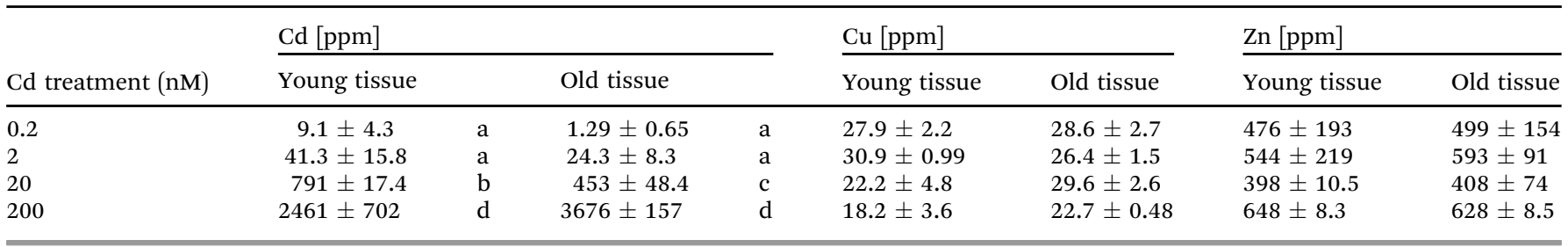

The treatments with more than $2 \mathrm{nM}$ Cd led to a significant increase $(P \leq 0.013)$ of up to more than $2500 \mathrm{ppm}$. Solely the plants treated with $20 \mathrm{nM} \mathrm{Cd}$ showed differences in $\mathrm{Cd}$ accumulation depending on the age of the tissue. No Cd was detected by $\mu$ XRF in the leaves of the control treatment. More importantly, Cd distribution changed depending on the Cd treatment concentration and time. With $2 \mathrm{nM}$ of $\mathrm{Cd}$, the distribution was homogeneous over the whole area of the leaf after 3 weeks of treatment, the maximal accumulation being $10.5 \mu \mathrm{M}$. After 6 weeks, a stronger accumulation of Cd within the mesophyll and the epidermis was observed and the maximal Cd concentration nearly tripled $(28 \mu \mathrm{M})$. There was no enhanced accumulation within the vein. A more defined distribution occurred after 3 and 6 weeks of $20 \mathrm{nM} \mathrm{Cd}$ treatment and the Cd concentration in the leaves was more than 20 -fold increased $(640 \mu \mathrm{M})$. Cd accumulation was detected mainly in the epidermis and the vein, but also in the mesophyll. After 6 weeks, Cd-accumulation in the epidermis was less pronounced compared to 3 weeks of $20 \mathrm{nM}$ of $\mathrm{Cd}$. An enhanced accumulation was also observed in the thorn (epidermal structure) of the plant treated with $20 \mathrm{nM} \mathrm{Cd}$ for 6 weeks. When $200 \mathrm{nM}$ were applied, Cd was mainly observed in the vein. The maximum $\mathrm{Cd}$ accumulation in the second replicate was even twice as high as in the shown one.

On the whole-plant level, $\mathrm{Cu}$ was in the range of $17-30 \mathrm{ppm}$ and decreased at higher Cd concentrations (Table 2). $\mu$-XRF revealed that $\mathrm{Cu}$ was always accumulated solely in the vein, no change in its distribution or concentration was observed in response to Cd toxicity (not shown).

On the whole-plant level, zinc accumulation ranged between 400 and $600 \mathrm{ppm}$ and was only slightly decreased at $20 \mathrm{nM}$ of Cd treatment. However, the decreases were not significant (Table 2). In contrast, the tissue-level distribution pattern of Zn strongly dependent on what $\mathrm{Cd}$ concentration was applied (Fig. 5). While in the lower Cd concentrations ( 0.2 and $2 \mathrm{nM}) \mathrm{Zn}$ was mainly found in the epidermis of the leaf, at higher Cd concentrations (20 nM) Zn was more homogeneously distributed. Zn concentration was highest after 3 weeks of treatment with $20 \mathrm{nM} \mathrm{Cd}(4.5,4.5$ and $3.2 \mathrm{mM})$. At the highest applied Cd concentration, $\mathrm{Zn}$ accumulation was reduced and mainly detected in the vein and the mesophyll, but hardly in the epidermis anymore, which is particularly surprising in view of the almost unchanged $\mathrm{Zn}$ concentration at the whole-plant level.

\section{Discussion}

The synthesis of phytochelatins is one major strategy of heavy metal(loid) detoxification. ${ }^{33,34}$ In many previous studies Cd-PCcomplexes were isolated from plants, e.g. transgenic and wild type Arabidopsis thaliana plants treated with $10 \mu \mathrm{M}$ of $\mathrm{Cd}^{35}$ To break the cell walls and to isolate the substances, plants were lyophilized and ground to a homogeneous mixture. During these processes all cell components get mixed and it cannot be assured that $\mathrm{Cd}$ was indeed bound to the PCs before disrupting the cells. Therefore we examined the different PC species rather than Cd-PC-complexes. In the present study we show that not only the concentration of the single PCs but also the occurrence of different $\mathrm{PC}$ species $\left(\mathrm{PC}_{2}\right.$ to $\left.\mathrm{PC}_{6}\right)$ in Ceratophyllum demersum is dependent on the applied Cd concentration, and that this occurs at several orders of magnitude lower Cd concentrations than previously known. A previous study on C. demersum treated with 5000 and $10000 \mathrm{nM}$ of Cd for a short period ( 2 or 4 days) revealed the induction of $\mathrm{PC}_{2}$ and $\mathrm{PC}_{3}$. After 4 days of treatment with $10000 \mathrm{nM} \mathrm{Cd}$, the amount of PCs decreased while the accumulation of Cd within the tissue continued to increase. ${ }^{36}$ The overall content of NP-SHs (non-protein thiols; including PCs) was significantly increased in the plants treated with $5000 \mathrm{nM} \mathrm{Cd}$, and highest in those plants treated for 4 days. In the present study, induction of phytochelatins started already in the low nanomolar range, and the strongest rise in their induction occurred at $20 \mathrm{nM} \mathrm{Cd}$, i.e. 250 times lower than the lowest $\mathrm{Cd}$ in the previous study. In the present study, also $\mathrm{PC}_{4}-\mathrm{PC}_{6}$ were detected in plants treated with the highest $\mathrm{Cd}$ concentration (200 nM), which was still 25 times less than the lowest Cd concentration in the study of Mishra and colleagues. ${ }^{36}$ However, they used the Hoagland solution, ${ }^{37}$ which contains Fe-EDTA and may have led to chelation of Cd ions. In different macrophytes (Pistia stratiotes; water lettuce) treated for 21 days with environmentally relevant concentrations of $\mathrm{Cd}(10 \mathrm{nM}$ to $1 \mu \mathrm{M}$ applied $\mathrm{Cd}$, but these authors also used EDTA), enhanced phytochelatin concentrations were detected from $20 \mathrm{nM}$ on, both in leaves and roots. ${ }^{38}$ The respective concentration was always higher in the shoots, while GSH was higher in roots. The involvement of PCs in Cd detoxification especially in non-hyperaccumulator plants is well documented and non-controversial. In the present study, however, we could show the dose-dependency for the different PC species under naturally occurring Cd concentrations and 
culture conditions. This revealed a switch-like induction, with different Cd concentration thresholds for different PC species. Thus an increase in Cd toxicity stress does not just lead to a further overall increase in PC synthesis, but to a change in PC composition. This may suggest that different PCs have different tasks (e.g. homeostasis vs. detoxification) or that plants only invest the synthesis effort into producing long-chain PCs once it becomes critical for survival, while for alleviating moderate toxicity only $\mathrm{PC}_{3}$ is formed.

Unlike $\mathrm{Cd}, \mathrm{Cu}$ is essential for plant growth. ${ }^{39,40}$ It is mainly required in at least six locations in a plant cell including the cytosol, the endoplasmic reticulum (ER), the inner membrane of the mitochondria, the stroma of the chloroplast, the thylakoid lumen and the apoplast. ${ }^{41} \mathrm{Cu}$ can be found in the active center of various enzymes, e.g. of plastocyanin, a small protein involved in the electron transfer from cytochrome $b_{6} f$ to the PSI reaction centre; the $\mathrm{Cu} / \mathrm{Zn}$ superoxide-dismutase ( $\mathrm{Cu} / \mathrm{Zn} \mathrm{SOD})$ and also in the cytochrome $c$ oxidase. ${ }^{42} 10 \mathrm{nM} \mathrm{Cu}$ were used for the stock cultures and within the Cd treatment as this had been found to be the optimal concentration for $C$. demersum (personal communication, G.T. \& H.K.). At $\mathrm{Cu}$ concentrations over the optimum value, the plants nevertheless cannot detoxify all $\mathrm{Cu}$ but need to retain the essential $\mathrm{Cu}$ for plastocyanin and other $\mathrm{Cu}$ containing enzymes. ${ }^{43}$ Metallothioneins (MTs; gene encoded and expressed metal-binding proteins) and PCs as well as high molecular weight ligands seem to be involved in the detoxification process. ${ }^{44}$ In this context, the non-induction of PCs by low Cu (Fig. 4) was expected, even though there have been studies indicating an increase in MTs activating the Cu-chelatereductase in pea plants at $\mathrm{Cu}$ deficiency. ${ }^{45,46}$ Apparently, only the highest of the applied $\mathrm{Cu}$ concentrations in this study induced enhanced PC production (Fig. 3). Around 400 ppm of $\mathrm{Cu}$ was accumulated by the plant at this concentration while the lower concentrations were below 100 ppm which clearly indicates the PC enhancement at the higher concentrations. ${ }^{43}$

The technique of $\mu$-XRF of frozen hydrated samples allows us to determine the distribution of heavy metal(loid)s in plants without chemical fixation and potential alteration and should be favored over techniques that require dehydration, resin embedding or fractionation. ${ }^{47}$ In combination with silencing or deleting genes that encode for metal transporters, $\mu$-XRF can also reveal information about metal homeostasis. ${ }^{48}$ Studies in which $\mu$-XRF was applied to detect Cd were mainly done with hyperaccumulator plants and the results may be very different in non-hyperaccumulators, especially because $\mathrm{Cd}$ will be bound to different ligands. ${ }^{31,34} \mathrm{Cd}$ distribution patterns were examined by $\mu$-XRF in two ecotypes of Sedum alfredii, one of which is a Cd-hyperaccumulator and one not. In the hyperaccumulator ecotype (HE), Cd was distributed very homogeneously across the stem cross section within the parenchymal tissue, with the exception of the vascular bundle where $\mathrm{Zn}$ was located. In the non-hyperaccumulator ecotype (NHE) Cd and $\mathrm{Zn}$ were distributed mainly in the cells surrounding the vascular bundle. ${ }^{49}$ Laser-ablation ICP-MS of whole unprepared leaf samples within the same study revealed an even distribution of Cd over the whole area (except the leaf tips) and the vein, and in the palisade mesophyll and the vascular bundle regarding the leaf cross section. In contrast, $\mathrm{Zn}$ accumulation was mainly found in the epidermal layers of the HE, but also in the vascular bundle. In this study, only leaf samples of Ceratophyllum demersum were subjected to $\mu$-XRF analyses. The distribution of $\mathrm{Cd}$ and $\mathrm{Zn}$ was mostly similar, but changing at higher $\mathrm{Cd}$ concentrations: in the plants subjected to control conditions or low non-toxic Cd concentrations, $\mathrm{Zn}$ was localized mainly in the epidermis cells (Fig. 5), whereas Cd was either not detected (control treatment), or found mostly all over the leaf (2 nM). With increasing $\mathrm{Cd}$ concentrations, a strong and increasing sequestration of $\mathrm{Cd}$ and also $\mathrm{Zn}$ into the vascular bundle and the thorn was observed. Metal sequestration into the epidermis is a phenomenon well-known for hyperaccumulator plants; it protects the more sensitive mesophyll from metal toxicity (e.g. $\mathrm{Zn}^{26} \mathrm{Ni}^{27}$ ). In Arabidopsis halleri, a Cd-hyperaccumulator, $\mathrm{Cd}$ and $\mathrm{Zn}$ accumulation was found to behave only somewhat similar, as sequestration was stronger in the mesophyll, while in the epidermis it was found specifically within the trichomes, unicellular leaf hairs on the surface of the leaves, ${ }^{50}$ which were located around the main vein. ${ }^{51}$ A changing distribution over time was observed in A. halleri by Huguet et al.: ${ }^{52}$ after 3 weeks of treatment, $\mathrm{Cd}$ accumulation occurred in the vein and petiole. After 9 weeks, more Cd was found within the leaves, towards the edges. Furthermore, the distribution of $\mathrm{Zn}$ was different from that of $\mathrm{Cd}$ at the leaf scale. ${ }^{52}$ The non-hyperaccumulator Arabidopsis thaliana also showed enhanced Cd accumulation in the trichomes. ${ }^{53}$ The sequestration into the leaf hairs and epidermis seems to be part not only of a detoxification mechanism, but also a defense strategy. Herbivores like snails will indispensably ingest the leaf hairs and other epidermal cells by moving over them and will be deterred from further feeding. ${ }^{50} \mathrm{~A}$ similar situation is also possible for the thorns in C. demersum.

Despite the induction of PCs at high Cd concentrations and their expected storage in vacuoles, highest amounts of Cd were observed in the vein at $200 \mathrm{nM} \mathrm{Cd}$. This may suggest that the applied Cd concentration could not be exported out of the vein into the mesophyll. Already from $20 \mathrm{nM}$ (3 weeks) onward, the distribution of $\mathrm{Cd}$ became less differentiated, suggesting limited export due to inhibited transporters. Cd shares chemical properties with $\mathrm{Zn}$ and $\mathrm{Cd}$ enters plants most likely via $\mathrm{Ca}$ channels or Zn transporters. ${ }^{10,54,55}$ Due to chemical similarity, $\mathrm{Cd}$ can replace $\mathrm{Zn}$ in the active center of enzymes ${ }^{56}$ and inhibit its uptake by competing for transporters or by interfering with the transporter's gene expression. ${ }^{57} \mathrm{Cd}$ can inhibit transporters and limit the uptake of other nutrients, and in the same way transporters localized in the vein can be inhibited. This could explain why high $\mathrm{Cd}$ had an effect on the distribution of $\mathrm{Zn}$ (Fig. 5). The high amount of Cd therefore most likely inhibited $\mathrm{Zn}$ distribution at the highest $\mathrm{Cd}$ concentration $(200 \mathrm{nM}, 3$ weeks), and after a longer treatment duration with moderately toxic Cd (20 nM, 6 weeks). In both samples, $\mathrm{Zn}$ was relocated from the epidermis to the vein (and the thorn). The export of $\mathrm{Zn}$ from the vein into the mesophyll will also be inhibited by $\mathrm{Cd}$, when the same transporters are used due to chemical similarity. This Cd-induced inhibition of $\mathrm{Zn}$ distribution, which will lead to 
$\mathrm{Zn}$ starvation of tissues outside the vein and possibly added $\mathrm{Zn}$ toxicity inside the vein, could be an important factor in overall $\mathrm{Cd}$ toxicity in the plants. Interestingly, this inhibited $\mathrm{Zn}$ export from the vein was not linked to inhibition of $\mathrm{Zn}$ uptake into the plant as measured at the whole-plant level. There was an increased $\mathrm{Zn}$ accumulation in the plant treated with $20 \mathrm{nM}$ for 3 weeks, probably showing a defense mechanism against moderately toxic $\mathrm{Cd}$. An increased uptake of $\mathrm{Zn}$ could ensure sufficient $\mathrm{Zn}$ within the tissue and has been observed in previous studies. ${ }^{58}$ However, $\mathrm{Zn}$ content in the young and old tissue of C. demersum did not alter due to Cd treatment (Table 2).

\section{Conclusion}

C. demersum can tolerate low or moderately toxic Cd concentrations due to upregulation of phytochelatin synthesis and sequestration into non-photosynthetic tissues. Toxicity of Cd inhibited export of $\mathrm{Zn}$ from the vein, and various phytochelatins were switchlike induced at individual Cd threshold concentrations. These aspects of toxicity and detoxification were induced already at very low and environmentally relevant $\mathrm{Cd}$ concentrations. The switch-like response of PC synthesis could be used as a toxicity marker in natural habitats.

\section{Experimental}

The submerged, rootless macrophyte Ceratophyllum demersum was used for the stress experiments. The strain was obtained from an aquaria shop and continuously cultivated since 2005 in hydroponic solution under $12 \mathrm{~h}$ day/12 h night light conditions provided by two Osram FLUORA ${ }^{\circledR}$ fluorescent and two warm white fluorescent tubes (Osram, München, Germany) and a temperature cycle from $18{ }^{\circ} \mathrm{C}$ at 6 a.m., over $20{ }^{\circ} \mathrm{C}$ at 9 a.m., to a maximum of $22{ }^{\circ} \mathrm{C}$ at 3 p.m., back to over $20{ }^{\circ} \mathrm{C}$ at 9 p.m. to $18{ }^{\circ} \mathrm{C}$ again at 6 a.m. The nutrient solution (Table 3) was optimized for growth of submerged macrophytes (personal communication from H.K., unpublished) and resembles the situation of typical oligotrophic waters, in particular soft waters. The $\mathrm{pH}$ was adjusted to 7.8 with $\mathrm{KOH}$. All experiments were carried out under simulations of natural light and

Table 3 Concentrations of the ions in the nutrient solution in $\mu \mathrm{M}$

\begin{tabular}{llll}
\hline Cations & \multicolumn{3}{c}{ Anions } \\
\hline $\mathrm{Ca}^{2+}$ & 80 & $\mathrm{BO}_{3}{ }^{3-}$ & 0.16 \\
$\mathrm{Co}^{2+}$ & 0.01 & $\mathrm{Cl}^{-}$ & 88.02 \\
$\mathrm{Cu}^{2+}$ & 0.01 & $\mathrm{CO}_{3}{ }^{2} / \mathrm{HCO}_{3}{ }^{-}$ & 100 \\
$\mathrm{Fe}^{3+}$ (aq.) & 0.2 & $\mathrm{CrO}_{4}{ }^{2-}$ & 0.002 \\
$\mathrm{~K}^{+}$ & 650 & $\mathrm{H}_{2} \mathrm{PO}_{4}{ }^{-} / \mathrm{HPO}_{4}{ }^{2-}$ & 2 \\
$\mathrm{Mg}^{2+}$ & 150 & $\mathrm{I}^{2+}$ & 0.05 \\
$\mathrm{Mn}^{2+}$ & 0.4 & $\mathrm{MoO}_{4}{ }^{2-}$ & 0.01 \\
$\mathrm{Na}^{+}$ & 60.1 & $\mathrm{NO}_{3}{ }^{2-}$ & 40 \\
$\mathrm{NH}_{4}{ }^{+}$ & 10 & $\mathrm{SO}_{4}{ }^{2-}$ & 150.5 \\
$\mathrm{Ni}^{2+}$ & 0.01 & & \\
$\mathrm{Zn}^{2+}$ & 0.05 & &
\end{tabular}

Others

Fe-EDDHA

0.2

Hepes temperature conditions: a $12 \mathrm{~h}$ sinusoidal light cycle with maximal irradiances at $750 \mu \mathrm{mol}$ photons $\mathrm{m}^{-2} \mathrm{~s}^{-1}$ (supplied by Dulux L 55 W/12-954, OSRAM München, Germany) and $12 \mathrm{~h}$ night; $19{ }^{\circ} \mathrm{C}$ at 6 a.m., $21.5{ }^{\circ} \mathrm{C}$ at 9 a.m., $24{ }^{\circ} \mathrm{C}$ at 3 p.m., $23{ }^{\circ} \mathrm{C}$ at 9 p.m., $19{ }^{\circ} \mathrm{C}$ at 6 a.m. For each treatment around $1.5 \mathrm{~g}$ (fresh weight) of plants were used. For the two experiments of PC-induction each aquarium contained 2 or 3 plants. The experiments used for metal accumulation and $\mu$-XRF were carried out with 2 or 4 plants. The number of individual plants was consistent for each concentration within the same experiment. Differences occurred due to weight and size of the plants at treatment start. Each aquarium contained $2 \mathrm{~L}$ of continuously aerated medium to secure a low biomass to water volume ratio. The nutrient solution was continuously exchanged (flow rate $0.5 \mathrm{~L} \mathrm{day}^{-1}$ ) to ensure that the metal uptake into the plants was limited only by the concentration, but not by the amount of nutrient solution available. After 1 week of acclimation to the high light conditions, cadmium was applied as $\mathrm{CdSO}_{4}$, and copper as $\mathrm{CuSO}_{4}$ to the medium. The concentrations were " 0 ", (background $\mathrm{Cd} / \mathrm{Cu} \sim 0.2 \mathrm{nM}$ ), 0.5, 1, 2, 5, 10, 20, 50, 100, and $200 \mathrm{nM}$. Epiphytic algae and cyanobacteria were removed weekly from the macrophytes by gentle brushing and the aquaria cleaned. During the treatment duration, stress symptoms were determined weekly by measuring chlorophyll fluorescence of individual leaves as described previously. ${ }^{47,59}$

For phytochelatin analyses, plants were harvested after 2 weeks of treatment, separated into young ( $4 \mathrm{~cm}$ from apex, $2 \mathrm{~cm}$ from branch) and old (remaining) parts, the respective weight was determined and the plants frozen in liquid nitrogen until further analyses. Plants from one $\mathrm{Cu}$ treatment were harvested after 4 weeks to ensure $\mathrm{Cu}$ limitation inside the plants. For $\mu$-XRF analyses, leaves from Cd treated plants after 3 and 6 weeks of treatment were prepared as described below.

\section{Phytochelatin extraction \& determination}

The harvested plant material was ground in a pre-cooled mortar in liquid nitrogen. The ground material was halved and transferred into two $2 \mathrm{ml}$ cups and covered with $1 \%$ formic acid in a concentration of $2 \mathrm{~mL} \mathrm{~g}^{-1}$ fresh weight. The material was thawed, and phytochelatins were extracted for 1.5 hours at $4{ }^{\circ} \mathrm{C}$. The cups were vortexed three times in between. The material was then centrifuged for $15 \mathrm{~min}$ at $2500 \times g$ at $5{ }^{\circ} \mathrm{C}$ using a swinging bucket rotor. The purple supernatant was transferred into new cups, rapidly frozen in liquid nitrogen and kept at $-80{ }^{\circ} \mathrm{C}$ until analysis.

The used synthetic PCs with a purity of $>95 \%$ were purchased from MoBiTec (Göttingen, Germany). A mixture of PCs with a concentration of $0.05 \mathrm{mM}$ each $\left(\mathrm{PC}_{2}-\mathrm{PC}_{6}\right)$ was prepared in $1 \%$ formic acid solution as external standard stock solution. Standard mixtures of $\mathrm{PC}_{2}$ to $\mathrm{PC}_{6}$ were used as calibrants. On the basis of the peak areas of the "Extracted Ion Chromatogram" (EIC) of the reduced and oxidized forms of the PCs the PC-specific calibrations were performed and the concentrations of the PCs in the extracts calculated. The limit of detection of $\mathrm{PC}_{3}$ was calculated to be $0.4 \mu \mathrm{M}$. The reproducibility (relative standard deviation) differs for the $\mathrm{PC}$ under investigations in the following order: $\mathrm{PC}_{2}$ and $\mathrm{PC}_{3}<5 \%, \mathrm{PC}_{4}<7.5 \%, \mathrm{PC}_{5}<9 \%$ and $\mathrm{PC}_{6}<15 \%$. 
Table 4 Parameters for LC-ICP-MS/ESI-MS

\begin{tabular}{|c|c|}
\hline LC-ICP-MS/ESI-Q-TOF-MS & Conditions \\
\hline \multicolumn{2}{|l|}{$\mathrm{LC}$} \\
\hline Column & $\begin{array}{l}\text { ZORBAX Eclipse Plus } \mathrm{C}_{18} \text { RRHD } \\
2.1 \times 50 \mathrm{~mm}, 1.8 \mu \mathrm{m}\end{array}$ \\
\hline Mobile phase & $\begin{array}{l}\text { Eluent A: } 0.1 \% \mathrm{HCOOH} \text { in water } \\
\text { Eluent B: } 0.1 \% \mathrm{HCOOH} \text { in acetonitrile }\end{array}$ \\
\hline Gradient & $0-3 \min 0 \% \mathrm{~B} ; 3-20$ min $0-100 \% \mathrm{~B}$ (linear) \\
\hline \multicolumn{2}{|l|}{ ESI-Q-TOF-MS } \\
\hline Polarity & Positive \\
\hline Fragmentor voltage & $175 \mathrm{~V}$ \\
\hline Capillary voltage & $3500 \mathrm{~V}$ \\
\hline Mass range & $500-3200 \mathrm{mu}$ \\
\hline Gas temperature & $325{ }^{\circ} \mathrm{C}$ \\
\hline Drying gas & $10 \mathrm{~L} \mathrm{~min}^{-1}$ \\
\hline Nebulizer pressure & $20 \mathrm{psi}$ \\
\hline Sheath gas temperature & $400{ }^{\circ} \mathrm{C}$ \\
\hline Sheath gas flow & $12 \mathrm{~L} \mathrm{~min}^{-1}$ \\
\hline Nozzle voltage & $2000 \mathrm{~V}$ \\
\hline \multicolumn{2}{|l|}{ ICP-MS } \\
\hline RF power & $1600 \mathrm{~W}$ \\
\hline Plasma gas flow rate & $\operatorname{Ar} 15 \mathrm{~L} \mathrm{~min}^{-1}$ \\
\hline Carrier gas flow & $0.6-0.7 \mathrm{~L} \mathrm{~min}^{-1}$ \\
\hline Sample depth & $6 \mathrm{~mm}$ \\
\hline Element monitored & $m / z 114\left(\mathrm{Cd}^{+}\right)$ \\
\hline
\end{tabular}

In all cases the peak areas for the oxPCs and redPCs were added and used for calculation of the concentration. After every 10 measurements a control standard was injected to check the performance of the instrument. The instrument was tuned daily to maintain the accurate mass analysis.

Phytochelatins were analyzed using an HPLC-ICP-MS/ESI-QTOF-MS system consisting of a UHPLC Series Infinity 1290 (degasser, binary pump, thermostated autosampler) coupled with an ICP-MS 7500ce and Accurate Mass Q-TOF LC/MS 6530 in parallel (all Agilent Technologies, Santa Clara, USA) by splitting the mobile phase 1:1 using an adjustable flow splitter (Analytical Scientific Instruments, CA, USA). The injection volume used was $20 \mu \mathrm{L}$. The samples were cooled to $278 \mathrm{~K}$ in the autosampler. The conditions for the separation and detection are listed in Table 4. To reduce carbon deposits on the sampler cone of the ICP-MS originating from acetonitrile in the mobile phase, a gas mix of $\mathrm{O}_{2} / \mathrm{Ar}(20 \% / 80 \%)$ was added to the carrier gas flow and the spray chamber was cooled. For data acquisition and qualitative analysis the MassHunter (MH) software and therein occurring tools (Agilent Technologies, Santa Clara, USA) were used. The free phytochelatins were identified by their retention time and accurate mass. Cadmium-PC-complexes are not stable under the acid extraction and analysis conditions that only the concentrations of the free $\mathrm{Cd}^{2+}$ were detected with element-selective ICP-MS detection at $\mathrm{m} / \mathrm{z} 111$ and an integration time of $0.5 \mathrm{~s}$.

\section{$\mu$-XRF}

For sample preparation, capillaries $(1 \mathrm{~mm}$ diameter, $0.1 \mathrm{~mm}$ wall; Hilgenberg $\mathrm{GmbH}$, Malsfeld, Germany) were cut to adequate sizes and filled with water. One leaf from the 7th nodium counted from the apex was inserted into the water filled capillary and fixed on a custom made sample holder. For calibration, we prepared an aqueous multielement standard containing $1 \mathrm{mM}$ each of $\mathrm{Na}_{3} \mathrm{AsO}_{4}, \mathrm{CdCl}_{2}, \mathrm{CrCl}_{3}, \mathrm{CuCl}_{2}$, $\mathrm{NaFe}(\mathrm{III})-\mathrm{EDTA}, \mathrm{NiCl}_{2}, \mathrm{ZnCl}_{2}$ in $20 \%$ glycerol and $5 \% \mathrm{HCl}$, adjusted to final volume with water and filled into the same capillaries as used for the leaves. A zero standard containing only $20 \%$ glycerol and $5 \% \mathrm{HCl}$ served as a negative control. An aqueous standard can be used as an approximation as frozen leaves consist of over $90 \%$ of water. The glycerol hereby serves as a C-matrix. The capillaries containing standards or leaves were shock frozen in supercooled isopentane $\left(-140{ }^{\circ} \mathrm{C}\right)$. After freezing, the samples were stored in liquid nitrogen until the analysis. To limit beam damage, throughout the measurement the sample was cooled in a cryostream to about $100 \mathrm{~K}$ (Cryocool LN3; Cryoindustries of America, Manchester, New Hampshire, USA). All $\mu$-XRF measurements were done at beamline $L$ of the synchrotron DORIS at the Deutsches Elektronen-Synchrotron (DESY, Hamburg, Germany). X-rays created in a bending magnet were monochromatized using a multilayer monochromator at $30.8 \mathrm{keV}$ with a bandpass of approximately $2.3 \%$. Focusing was achieved using a single-bounce capillary to approximately $10 \mu \mathrm{m}$ spotsize in both horizontal and vertical dimensions. $\mu$-XRF tomography was done approx. $3 \mathrm{~mm}$ above the branching point of the leaf with a step size of $5 \mu \mathrm{m}$ and a dwell time of $0.8 \mathrm{~s}$ per step. Ninety one linescans were measured, with the sample being rotated by $2^{\circ}$, yielding a $180^{\circ}$ tomogram. Two fluorescence detectors (Vortex-60 EX/Vortex-90 EX; SII Nanotechnology USA Inc., Northridge, California, USA) were used under $90^{\circ}$ and $270^{\circ}$ with respect to the incident beam to maximize detected fluorescence counts from the sample while minimizing background caused e.g. by elastic scattering due to the polarized nature of the synchrotron radiation. The detected $\mu$ XRF spectra were fitted using PyMca. ${ }^{60}$ The fluorescence line areas were then normalized to $100 \mathrm{~mA}$ DORIS current, the resulting sonograms were tomographically reconstructed with $\mathrm{XRDUA}^{61}$ using the maximum likelihood expectation maximization ("MLEM") algorithm. Absolute concentrations were obtained using the tomographic reconstruction of the multielement-standard measured in the identical geometry.

\section{Determination of accumulated elements}

After 6 weeks of Cd-treatment, plants were harvested, separated into young and old parts and lyophilized for 48 hours. 5-10 mg of the material was put into acid-washed $\left(5 \% \mathrm{HNO}_{3}\right)$ glass tubes and digested in $500 \mu \mathrm{L}(85: 15 \%)$ nitric-perchloric acid for $30 \mathrm{~min}$ at room temperature and then gradually heated up to a maximum of $195{ }^{\circ} \mathrm{C}$ until all liquid was vaporized. ${ }^{62}$ The remaining ashes were re-dissolved in $0.5 \mathrm{~mL} 5 \% \mathrm{HCl}$, and gradually heated to $80{ }^{\circ} \mathrm{C}$. After cooling, the volume was filled to $1.5 \mathrm{~mL}$ with $\mathrm{ddH}_{2} \mathrm{O}$ and used for analyzing the components using a graphite furnace atomic absorption spectrometer (GBC 932 AA with GF 3000, Braeside, VIC, Australia). Standard solutions for $\mathrm{Cd}, \mathrm{Zn}$ and $\mathrm{Cu}$ were diluted from AAS Standards (TraceCERT, Sigma-Aldrich, St. Louis, MO, USA). Digested plant samples were appropriately diluted to the optimal detection range with ultrapure $1.66 \% \mathrm{HCl}$ (ROTIPURAN ultra, Roth, Karlsruhe, Germany). 


\section{Acknowledgements}

We thank DESY for providing beamtime at the DORIS beamline L, and Karen Appel and Manuela Borchert for their support during our $\mu$-XRF measurements. We are grateful for the financial support by the DFG (grant KU 1495/8) and basic funding of Universität Konstanz to H.K.

\section{Notes and references}

1 M. J. McLaughlin, D. R. Parker and J. M. Clarke, Field Crops Res., 1999, 60, 143-163.

2 Zweckverband Bodensee-Wasserversorgung, http://www. zvbwv.de/fileadmin/user_upload/PDF/Jahresmittelwerte2012.pdf.

3 M. Petri, in The Rhine, ed. T. P. Knepper, Springer Verlag, Berlin, 2006, vol. 5L, pp. 127-138.

4 Schadstoffuntersuchungen in Oberflächengewässern Mecklenburg-Vorpommerns im Zeitraum 2007-2011, Schadstoffe zur Bewertung des chemischen Zustands gemäß Oberflächengewässerverordnung (OGewV), Herausgeber: Landesamt für Umwelt, Naturschutz und Geologie MecklenburgVorpommern.

5 J. E. Fergusson, R. W. Hayes, T. S. Yong and S. H. Thiew, N. Z. J. Sci., 1980, 23, 293-310.

6 S. I. Ahmed, A. Sabo and D. D. Maleka, ATBU J. Environ. Technol., 2011, 4, 49-56.

7 T. W. Lane and F. M. M. Morel, Proc. Natl. Acad. Sci. U. S. A., 2000, 97, 4627-4631.

8 S. A. Hasan, Q. Fariduddin, B. Ali, S. Hayat and A. Ahmad, J. Environ. Biol., 2009, 30, 165-174.

9 E. Andresen and H. Küpper, in Cadmium: From Toxicity to Essentiality, ed. A. Sigel, H. Sigel and R. K. O. Sigel, Springer Science + Business Media B.V., Dordrecht, 2013, vol. 11, ch. 13, pp. 395-413.

10 S. Clemens, Planta, 2001, 212, 475-486.

11 S. Clemens, Biochimie, 2006, 88, 1707-1719.

12 G. Zhang, M. Fukami and H. Sekimoto, Field Crops Res., 2002, 77, 93-98.

13 J. Dong, F. Wu and G. Zhang, Chemosphere, 2006, 64, 1659-1666.

14 M. P. Benavides, S. M. Gallego and M. L. Tomaro, Braz. J. Plant Physiol., 2005, 17, 21-34.

15 E. Grill, E.-L. Winnacker and M. H. Zenk, Science, 1985, 203, 674-676.

16 O. K. Vatamaniuk, E. A. Bucher, J. T. Ward and P. A. Rea, J. Biol. Chem., 2001, 276, 20817-20820.

17 P. A. Rea, Physiol. Plant., 2012, 145, 154-164.

18 E. Grill, E.-L. Winnacker and M. H. Zenk, Proc. Natl. Acad. Sci. U. S. A., 1987, 84, 439-443.

19 M. Wink, J. Exp. Bot., 1993, 44, 231-246.

20 A. J. M. Baker, S. P. McGrath, R. D. Reeves and J. A. C. Smith, in Phytoremediation of Contaminated Soil and Water, ed. N. Terry and G. Bañuelos, Lewis Publishers, Boca Raton, FL, 2000, pp. 85-107.

21 H. Küpper and B. Leitenmaier, in Cadmium: From Toxicity to Essentiality, ed. A. Sigel, H. Sigel and R. K. O. Sigel,
Springer Science + Business Media B.V., Dordrecht, 2013, vol. 11, ch. 12, pp. 373-393.

22 M. J. Milner and L. V. Kochian, Ann. Bot., 2008, 102, 3-13.

23 R. S. Boyd and S. N. Martens, Oikos, 1994, 70, 21-25.

24 S. N. Martens and R. S. Boyd, Oecologia, 1994, 98, 379-384.

25 R. F. Jiang, D. Y. Ma, F. J. Zhao and S. P. McGrath, New Phytol., 2005, 167, 805-814.

26 H. Küpper, F. Zhao and S. P. McGrath, Plant Physiol., 1999, 119, 305-311.

27 H. Küpper, E. Lombi, F. J. Zhao, G. Wieshammer and S. P. McGrath, J. Exp. Bot., 2001, 52, 2291-2300.

28 B. Frey, C. Keller, K. Zierold and R. Schulin, Plant, Cell Environ., 2000, 23, 675-687.

29 K. Vogel-Mikus, M. Regvar, J. Mesjasz-Przbylowicz, W. J. Pryzbylowicz, J. Simcic, P. Pelicon and M. Budnar, New Phytol., 2008, 179, 712-721.

30 S. Huguet, S. Soussou, J. C. Cleyet-Marel, N. Trcera and M.-P. Isaure, E3S Web of Conferences, 2013, 19008, 1-4.

31 H. Küpper, A. Mijovilovich, W. Meyer-Klaucke and P. M. H. Kroneck, Plant Physiol., 2004, 134, 748-757.

32 N. R. Baker, Annu. Rev. Plant Biol., 2008, 59, 89-113.

33 J. L. Hall, J. Exp. Bot., 2002, 53, 1-11.

34 C. Cobbett and P. Goldsbrough, Annu. Rev. Plant Biol., 2002, 52, 159-182.

35 B. B. M. Sadi, A. P. Vonderheide, J.-M. Gong, J. I. Schroeder, J. R. Shann and J. A. Caruso, J. Chromatogr., B: Anal. Technol. Biomed. Life Sci., 2008, 861, 123-129.

36 S. Mishra, R. D. Tripathi, S. Srivatava, S. Dwivedi, P. K. Trivedi, O. P. Dhankher and A. Khare, Bioresour. Technol., 2009, 100, 2155-2161.

37 D. R. Hoagland and D. I. Arnon, Calif. Agr. Expt. Sat. Circ., 1950, 347, 1-32.

38 C. Wang, L. Y. Wand and Q. Sun, Water Environ. Res., 2010, 82, 147-154.

39 A. L. Sommer, Plant Physiol., 1931, 6, 339-345.

40 C. B. Lipman and G. McKinney, Plant Physiol., 1931, 6, 539-599.

$41 \mathrm{H}$. Marschner, Mineral nutrition of higher plants, Academic Press, London, 2nd edn, 1995.

42 H. Yamasaki, M. Pilon and T. Shhikanai, Plant Signaling Behav., 2008, 4, 231-232.

43 G. Thomas, H.-J. Stärk, G. Wellenreuther, B. C. Dickinson and H. Küpper, Aquat. Toxicol., 2013, 140-141, 27-36.

44 V. P. Kholodova, E. M. Ivanova and V. V. Kuznetsov, in Detoxification of Heavy Metals, ed. I. Sherameti and A. Varma, Springer-Verlag, Berlin, 2011, ch. 8, pp. 143-167.

45 A. P. Fordham-Skelton, J. R. Wilson, Q. Groom and N. J. Robinson, Acta Physiol. Plant., 1997, 19, 451-457.

46 R. M. Welch, W. A. Norvell, S. C. Schaefer, J. E. Shaff and L. V. Kochian, Plant, 1993, 190, 555-561.

47 T. Punschon, M. L. Guerinot and A. Lanzirotti, Ann. Bot., 2009, 103, 665-672.

48 S. A. Kim, T. Punshon, A. Lanzirotti, L. Li, J. M. Alonso, J. R. Ecker, J. Kaplan and M. L. Guerinot, Science, 2006, 314, 1295-1298. 
49 S. Tian, L. Lu, J. M Labavitch, X. Yang, Z. He, H. Hu, R. Sarangi, M. Newville, J. Commisso and P. Brown, Plant Physiol., 2011, 157, 1914-1925.

50 H. Küpper, E. Lombi, F. J. Zhao and S. P. McGrath, Planta, 2000, 212, 75-84.

51 N. Fukuda, A. Hokura, N. Kitajima, Y. Terada, H. Saito, T. Abe and I. Nakai, J. Anal. At. Spectrom., 2008, 23, 1068-1075.

52 S. Huguet, V. Bert, A. Laboudigue, V. Bartès, M.-P. Isaure, I. Llorens, H. Schat and G. Sarret, Environ. Exp. Bot., 2012, 82, 54-65.

53 M.-P. Isaure, B. Fayard, G. Sarret, S. Pairis and J. Bourguignon, Spectrochim. Acta, Part B, 2006, 61, 1242-1252.

54 L. Perfus-Barbeoch, N. Leonhart, A. Vavasseur and C. Forestier, Plant J., 2002, 32, 539-548.
55 S. Tian, L. Lu, X.-E. Yang, J. Labavitch, Y.-Y. Huang and P. Brown, New Phytol., 2009, 182, 116-126.

56 P. Aravind and M. N. V. Prasad, J. Anal. At. Spectrom., 2004, 19, 52-57.

57 H. Küpper and L. V. Kochian, New Phytol., 2010, 185, 114-129. 58 I. M. McKenna, R. L. Chaney and F. M. Williams, Environ. Pollut., 1993, 79, 113-120.

59 H. Küpper, A. Parameswaran, B. Leitenmaier, M. Trtilek and I. Setlik, New Phytol., 2007, 175, 655-674.

60 V. A. Solé, E. Papillon, M. Cotte, P. Walter and J. Susini, Spectrochim. Acta, Part B, 2007, 62, 63-68.

61 W. De Nolf and K. Janssens, Surf. Interface Anal., 2010, 42, 411-418.

62 F. Zhao, S. P. McGrath and A. R. Crosland, Commun. Soil Sci. Plant Anal., 1994, 25, 407-418. 